\title{
Changes of Form of Malay Traditional Houses in Medan and Surroundings
}

\author{
Imam Faisal Pane ${ }^{1}$, Hilma Tamiami Fachrudin ${ }^{2}$ \\ ${ }^{1}$ Department of Architecture, Faculty of Engineering, Universitas Sumatera Utara Indonesia. \\ ${ }^{1}$ Laboratory History, Theory, and Criticism of Architecture, Department of Architecture, Universitas \\ Sumatera Utara Indonesia. \\ 2Department of Architecture, Faculty of Engineering, Universitas Sumatera Utara Indonesia. \\ Email: imam.faisal@usu.ac.id
}

\begin{abstract}
:
Malay Architecture is one of the architectures that developed in Medan City and its surroundings. Malay ethnicity has existed and developed in this area marked by the presence of the Deli Malay Sultanate whose Kingdom capital is in Medan. With the existence of this Sultanate, the existence of Malay architecture is getting stronger and influencing the community, especially for the Malay community. This article aims to look at the development of Malay architecture nowadays with various influences that come from everywhere. This influence is certainly related to the form of this building which changes follow the times. Observation locations are in Medan and its surrounding areas, namely Langkat and Serdang Bedagai. Qualitative methods are used to see physical facts in the field which are corroborated by the questionnaire as a form of respondents' expressions. The results obtained are some changes to the building caused by the variety of activities owned by residents of the house so that it requires space that affect the changes in the form and function of the building. Overall, the building owner still maintains the characteristics of Malay traditional architecture, especially the use of ornaments or decoration on the building.
\end{abstract}

Keywords:

Malay architecture; form and function; Medan and its surroundings

\section{Introduction}

Culture is the result of human activities. The journey of cultural development is in line with the needs which raise to sustain the life. The result of culture is admitted by a group of people as a guide in life, beside that the result can be said to be artifacts that have their own characteristics. Artifacts that are the result of this culture characterize where the culture develops, in addition to artifacts that function as tool in daily activities, it is also necessary to become as a place to live. This shelter finally creates a unique architecture with their respective cultures.

Along with the development of architecture, the development of culture is also closely related to architecture. The architecture which is present is a representation of the local culture, cultural difference in a place gives a difference to the architecture. As Batak Toba Architecture is different from Javanese Architecture, this shows that the culture that develops is closely related to its architectural form. North Sumatra is one of the provinces in Indonesia which is located on the island of Sumatra and Medan is the capital of this province. This city is quite unique because it is inhabited by various ethnic groups from within and outside of North Sumatra. Malay ethnic is ethnic who lived in this area for a long time, the Deli Malay kingdom which moved its capital to Medan from Labuhan in 1891 which made the city rapid and thriving (Sinar, 2011). Beside that, the kingdom of Serdang also built its kingdom in the 


\section{Britain International of Humanities and Social Sciences (BIoHS) Journal \\ ISSN: 2685-3868(Online), 2685-1989(Print) \\ Vol. 2, No. 2, June 2020, Page: 495-502}

area which is now known as Serdang Bedagai. In addition to the Deli and Serdang Sultanate, Langkat Sultanate also built its territory and established its kingdom around Tanjung Pura. These three sultanates are Malay sultanates that provide architectural features and varieties in their region.

With a strong background so that the Medan City area and its surroundings can be said that it has an identity and existence for the development of Malay Architecture. Humans since ancient times have known shelter but they have not used the term of architecture. This shelter starts from a cave and after the residents settle in a place then the building for housing begins to built. In the activities of their life, humans always interact and form life patterns that systematically regulate the way of life in society. This procedure is called culture and aspects of this culture that produce characteristics depending on where the culture borns and develops. The ongoing culture forms a pattern of sedentary life and build permanent settlements. This place of residence is called architecture and its development is along with the history of civilization from humans themselves (Rapoport, 1969). Architecture that grows and develops in a place is a reflection of the customs that bind to an area.

These customs and traditions are different from one region to another region because of different backgrounds too. Indonesia which has diverse customs shows that there are diverse cultures too. In the days of ancestors, the need for shelter was interpreted as the process of ancestors' settling in somewhere and surviving there. Activities in survival produce traditions that survive until now and are called Culture. This culture produces traditions that are continuously present to spread color to an area or region.

Medan and the surrounding area is an area that is closed with Malay customs. This custom is still maintained and carried out by its successors. Its development is in line with the development of architecture, as part of cultural representation. Changing times have a significant impact on the development of local traditional architecture. Postmodern has a major influence on the appearance of buildings and makes traditional architecture as the spirit of buildings at its time. Even though it is not same with the past but buildings with Malay characteristics can still be found and are called Neo-Vernacular styles. The term of vernacular was pioneered by Bernard Rudofsky (1964) who stated that architecture that developed in a society without the role of an architect also had the potential to be considerated. This term is combined with traditional architectural terms that make these two terms have the same level. But in general it is different because traditional architecture is always related to the preferences of the people's trust while the vernacular is related to the material and technology of the community which are used when it was built. Yet, the term of Neo-Vernacular continues to be used and up to now to mention buildings with the latest technology but with the spirit of the past.

The development of traditional architecture in modern times uses the term of Vernacular / Neo-Vernacular Architecture, especially developing in the Western world. This vernacular development still holds on to the local culture due to local materials and technology. This culture which is held firmly keeps this traditional architecture surviving in a form that has also experienced the changes. According to Koentjaraningrat, 1990 that culture is a collection of people' ideas and concepts which have physical form. This form is formed diversely depending on the conditions of the local community. This form is seen on physical form that changes as a result of non-physical factors which also change. 
The development of Malay architecture in Medan and its surrounding areas at this time tends not to be seen anymore, even if it still exists on a small scale. The development of modern architecture reduces the role of culture in forming architecture, although this era is postmodern however there is not seen too much at the role of culture in impacting architecture as a whole. While the identity of culture can be represented by the existence of architecture (Abel, 1997), this thing makes it necessary to prioritize the role of culture in developing the presence of architecture in an area, especially Malay culture in Medan.

The physical form of this vernacular architecture can form an identity and display something that represents the local culture. In this study the object of study is the Malay traditional house which is located in Medan and its surroundings. In general, this house building is a staging house with wooden structure and construction. There are parts made of concrete or brick those are on the stairs into the house. In general the typology of Malay traditional house is divided into several parts, namely Lobby (Anjung), Main House (living room and bedroom) and Kitchen (Penanggah). These spaces are a unified Malay traditional house (Figure 1).
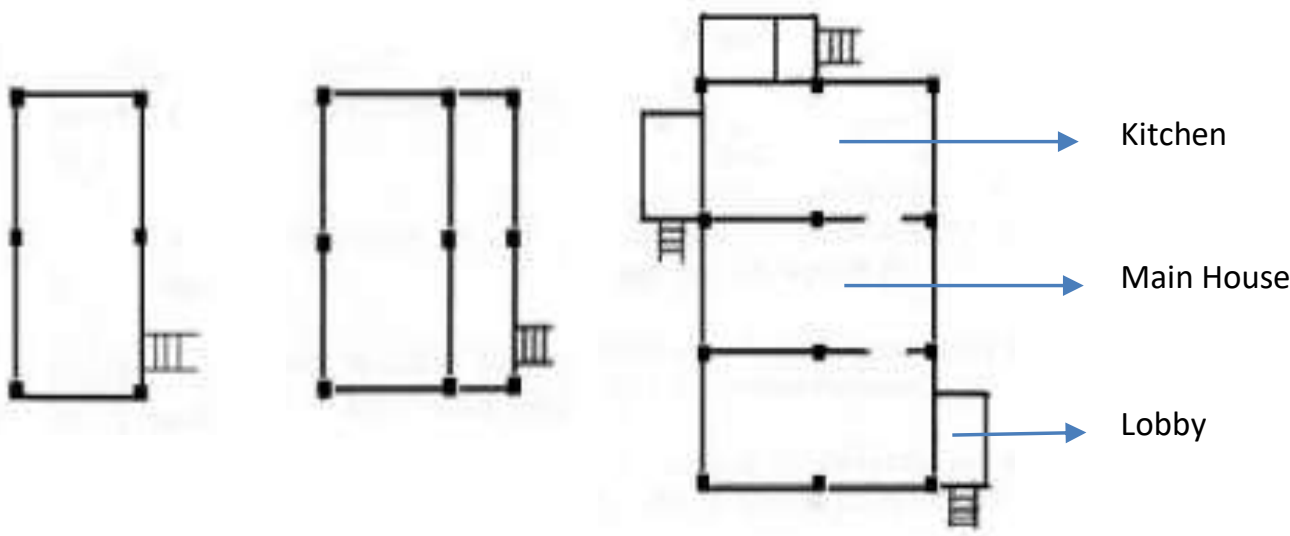

Figure 1. Morphology of Malay Traditional Houses (Source: Amran E.Prawoto)

Malay traditional house has a characteristic in the division of spaces, there is relation between one room and another room. The space which is created represents the interaction between the occupant in accordance with the beliefs and traditions that they hold firmly. In general, the characteristics of a Malay traditional house are buildings that have an east and west orientation (according to Islam), in the inside of the house there is a family room, living room and kitchen and the house is a work of art that has philosophical and cultural values.

Every room in a traditional Malay house does not have a solid wall but only in the form of a divider from cloth or curtains, because this room can get functions that interact with one another. From this morphology or form of Malay traditional house, it can be seen the typology of the space inside. In general, the shape of the house tends to be square with the front and rear stairs in the house. The three parts of the house are explained as follows:

a. Anjung

Anjung is generally located at the front of Malay traditional house and is directly related to the main house and does not have a full wall. Anjung is divided into 3 (three), namely Anjung Jatuh functions to receive guests and place to put goods for daily needs and different floor height from the main house. Anjung Luar, located at jutting forward from the main house, functions as a place to receive guests and playing for children. Anjung Dalam does not have different floor height and functions to receive important guests at certain events. 


\section{b. Main House}

This section is the main part of Malay traditional house. It also called as the mother's house as a tribute to the respected mother. In this part, it is divided into 3 (three) parts, namely the front room, a room that functions as a place to rest or stay overnight for family guest. Middle room, living room and close family and has room or chamber in accordance with the size of the house. Interior Room, a space, serves room for women parents and girls while boys who are 7 years old sleep in the middle room.

\section{c. Kitchen}

This part is located at the back of the house but its presence is a representation of the role of women in the house. No particular one who can enter the kitchen because it is the most important part of the house. The kitchen is divided into 2 (two) namely Telo Room, which is space that is between the main room and the kitchen which functions as a place of equipment. While the kitchen functions as a place for cooking and gathering, especially women. This kitchen also functions as a place for parents to give their children insight and advice.

\section{Research Method}

In conducting research that has been conducted used descriptive methods on qualitative scale. This method is used to see the facts on the field that are scattered in Medan city and its surrounding areas. The qualitative method uses an inductive approach to find generalizations of research results (Moleong, 2004; Sugiyono, 2009). The analysis also uses an inductive approach by using theories, especially the possibility of changes in form and function that occur on the object of research studies.

Collecting data is through field visits to the object of research and record with the camera to the building which become case study. The first building is in Langkat while the second and third buildings are in Serdang Bedagai. Both are areas that are still filled with Malay vernacular buildings that still characterize Malay tradition.

Another survey tool is the usage of questionnaires to strengthen the analysis based on the opinions of respondents. The selection of respondents is by random selection for those who stay in the area of research object. Each research area was examined by taking 15 respondents and the total respondents were 45 people.

Some of the questions asked are as follows:

- What do you think of the appearance of this Malay Traditional House?

- Is this house exactly the same as the Malay traditional house?

- Do you agree that buildings in this area have Malay characteristics?

- What rooms do you add or subtract?

- Does building ornament become your consideration?

These questions are to see the development of Malay vernacular architecture and morphology that occur as a result of the space needs at present. The questionnaire was done by way of face to face with respondents in the form of a list of questions that were equipped with personal data of the respondent.

In the research stages, the initial stage is collecting data in the form of primary and secondary data. Primary data obtained from direct observation of Malay traditional houses in the city of Medan and its surrounding areas, this data is also added with field data in the form 
of questionnaires to get opinions from the public. While secondary data is in the form of a collection of photographs and literature as a reference from this study. According to Sudradjat, 2014 direct and indirect observations are to take data by observing the conditions of the research site. This initial stage explains that observations made to collect field data which are useful for the next stages.

The criteria for collecting data are houses that are 50 years old or older and still retain Malay characteristics, especially the stage model. After the data is collected and then compiled according to research needs, the next step is the analysis and conclusion stage. Data analysis is the stage where the data that has been obtained in the field along with the theory is tested with an inductive approach. This approach is used to examine the phenomenon of shifting or changing spatial patterns in Malay traditional houses which seen from the function, shape and image of the building. After being analyzed, then it can be drawn the conclusions and recommendations that are useful to enrich the science of architecture.

\section{Discussion}

Referring to the survey result of questionnaire from respondents in Langkat, the appreciation of the existence of Malay traditional houses is quite high. There are $93 \%$ of respondents who answered agree that in this area, the building has Malay characteristics. The time development is not unstoppable anymore; additional space is needed to adapt the activities at present. Respondents stated that the spaces needed to be added such as the mosque, room and kitchen as shown in Figure 2 below:

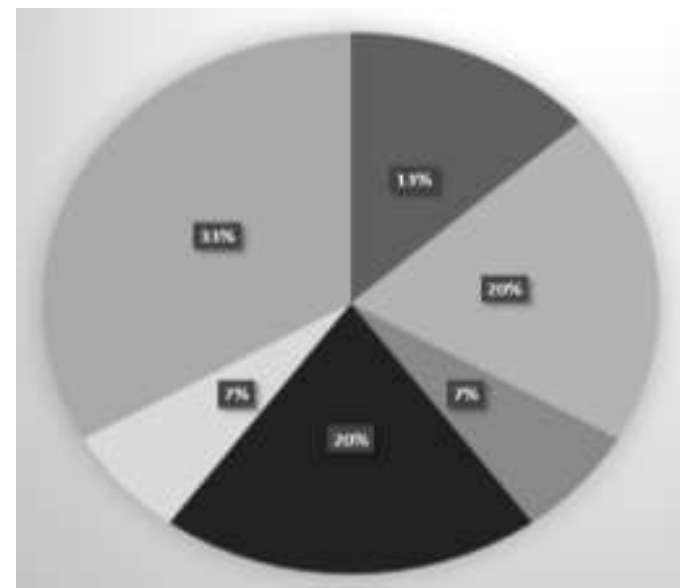

- To add prayer room

- To add room

O To enlarge the terrace

- To enlarge the family room

O To enlarge the kitchen

O None

Figure 2. Addition of Spaces in Tanjung Pura Traditional House

Some changes occurred in research case studies. Functions and needs of space make space patterns change according to current needs. In doing their daily life, Malay community always refers to the Malay custom, the Islamic rules and the local climate. Those three are a unity in life, including architecture. In doing their life, Malay community always uses these three things; it can be seen from the addition of a small mosque in the house.

MABMI Building Stabat (Langkat Regency) which becomes research case study shows that the Malay traditional house building has changed the function of the building into a meeting hall for Malay people in Langkat and its surrounding. This situation is a social cohesion which is needed to reinforce local culture (Carrà, 2016). The shape of the building changes according to the needs of space, especially accommodating meetings. The image of the building still looks like Malay traditional house because of the ornamentation that is still maintained until now (Figure 3). 

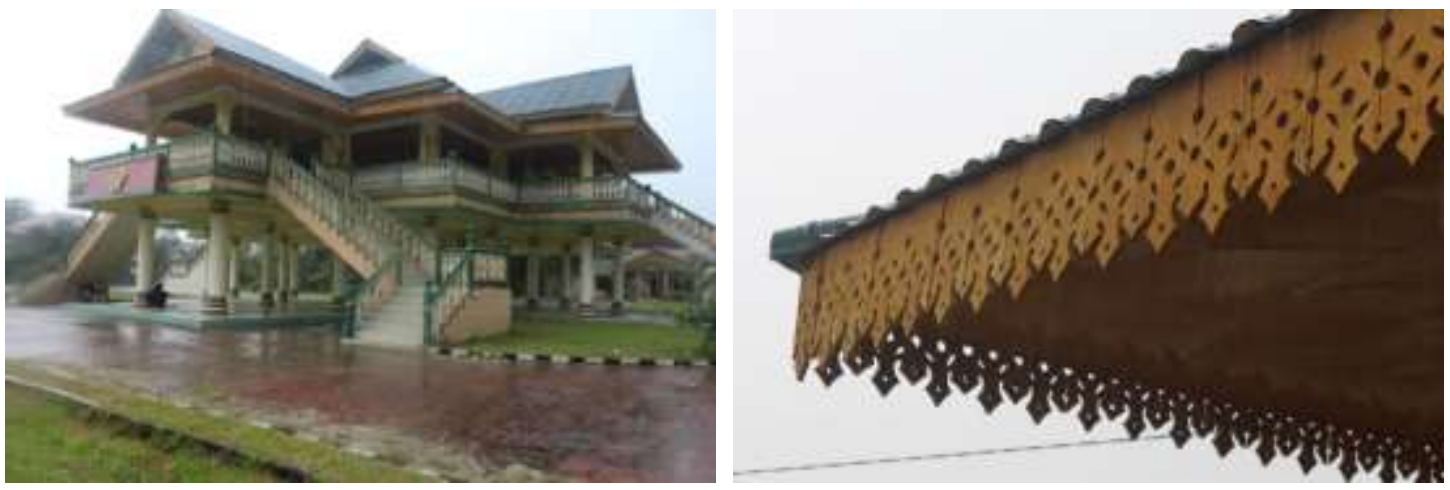

Figure 3. MABMI Building Stabat, Langkat Regency

The other research location is in Serdang Bedagai Regency. In the first house that becomes the object of research is looked the material changes at the bottom structure of the house building. The material is no longer made of wood but it is replaced by concrete in columns that support the floor building. On the walls of the building is still using wood or boards, for the roof material is already using zinc and the shape of the roof is a gable (Yuan, 1987). As function of this building, it functions as a residence and there is space under the building. Some new materials such as wooden ceilings were added to this house. From the view of the building as a whole, the image which is displayed shows the figure of Malay traditional house with ornamentation on the fascia board and stairs and also terrace on the front of the building (Figure 4).
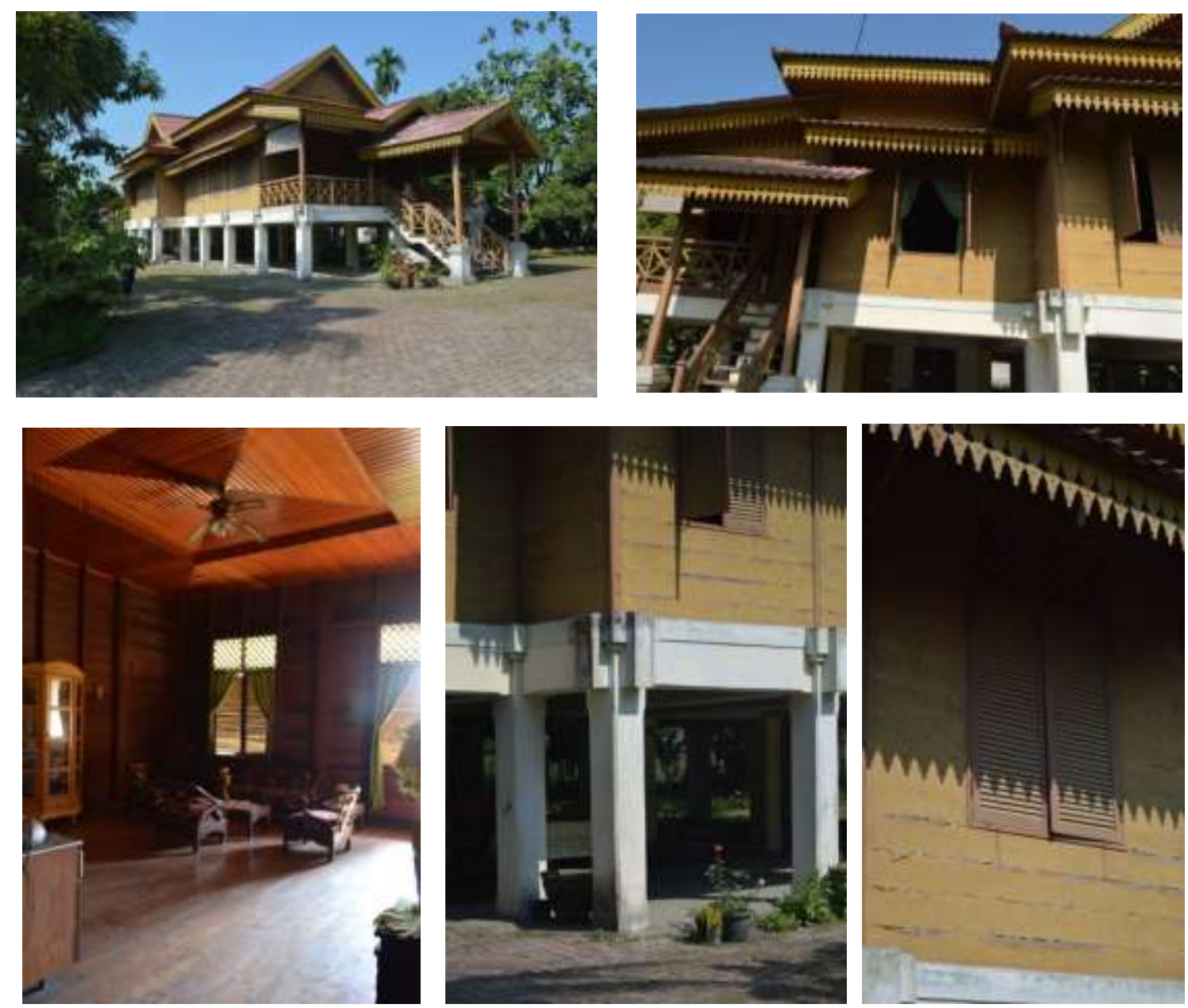

Figure 4. Malay House in Serdang Bedagai Regency-1 
The 3rd research location is in Serdang Bedagai Regency too, a house that still uses Malay Architecture style. The condition of the house still looks good but at the bottom there is only a pit under the front side of the house. In the middle of the house, space underneath is no longer available. On the terrace, it still shows the atmosphere of the Malay house which is seen at entrance staircase which forward to the terrace of the house surrounded by Malay wood carvings around the terrace. On the fascia board part, Malay ornamentation is still visible. The roof shape of shield model (Yuan, 1987) and roofing material are no longer use palm fibers but zinc. In general, Malay image is still maintained in this building (Figure 5).
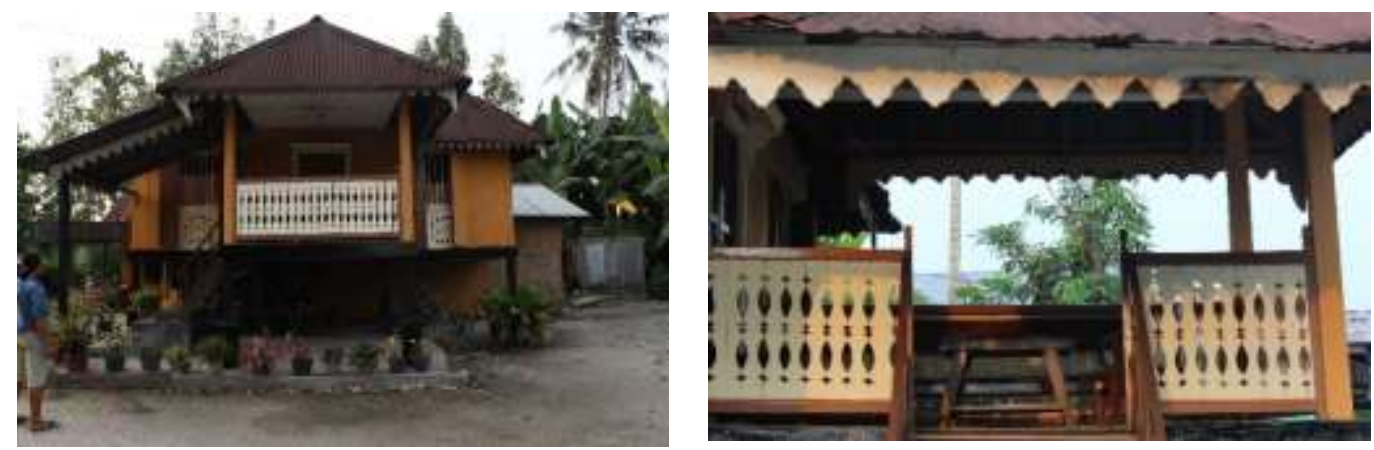

Figure 5. Malay House in Serdang Bedagai Regency-2

\section{Conclusion}

From the three research objects are got the results that the development of Malay traditional architecture still retain their characteristics, especially from the form, function and image of the building. The use of ornaments is still used to get the image of Malay architecture. In line with the times, the morphology of the house changes because of developing the needs and increasing interaction as effect of current activities. Overall results of this research can be seen in the following table (Table 1).

Table 1. Research Results

\begin{tabular}{llll}
\hline & Langkat & Serdang Bedagai-1 & Serdang Bedagai-2 \\
\hline Building Function & Building with & Residence with the & Residence with the \\
& additional space & addition of space & addition of space \\
& functions & functions & functions
\end{tabular}

Building Form

Building Image
Adjusting to function, there are large meeting rooms

Many changes, especially the form of the building and the use of glass windows, but Malay ornaments are still used as a hallmark of Malay Architecture
Square form of the building that extends backward according to the needs of space

The use of concrete structures at the bottom of the building but overall still displays the impression of Malay Architecture
Still maintaining the old form and there is additional space

The front is a porch or terrace that has stairs as a characteristic of Malay Architecture 


\section{Acknowledgment}

Thank you from the authors to Universitas Sumatera Utara for funding this research in the Talenta program with no. Contract 2590 / UN5.1.R / PPM / 2018 date March 16, 2018. Thank you also to students of the Department of Architecture who helped in finding data of research object.

\section{References}

Abel, Chris. (1997), Architecture and Identity : Towards a global eco-culture, Architectural Press, Butterworth-Heinemann.

Carrà, Natalina (2016), Heritage / Culture and social cohesion in the project of Metropolitan City, Procedia-Social Behavioral Sciences 223, p.583-589.

Koentjaraningrat (1990), Pengantar Ilmu Antropologi, Jakarta : PT.Rineka Cipta.

Moleong, Lexy J. (2004), Metoda Kajian Kualitatif, Remaja Rosdakarya. Bandung.

Rapoport, Amos. (1969), House Form and Culture, Englewood Cliffs : Prentice Hall.

Rudofsky, Bernard (1964), Architecture without architect, an introduction to nonpedigreed architecture, The Museum Modern of Art: Distributed by Doubleday, Garden City, N.Y.

Sinar, T. Lukman (2011), Sejarah Medan Tempoe Doeloe, Sinar Budaya Group, Medan.

Sudradjat, Iwan (2004) dalam Roesmanto, Totok (ed), Penelitian Arsitektur : metoda \& terapannya, Magister Teknik Arsitektur Universitas Diponegoro, Semarang.

Sugiyono (2009), Metoda Penelitian Kualitatif dan Kuantitatif dan R\&D. CV. Alfabeta Bandung.

Yuan, Lim Jee (1987), The Malay House (Rediscovering Malaysia's Indigenous Shelter System), Institut Masyarakat, Pulau Pinang. 